\title{
Competition Policy, Bailouts, and the Economic Crisis
}

\section{Bruce Lyons}




\section{Competition Policy, Bailouts, and the Economic Crisis}

Bruce Lyons*

The aims of this paper ${ }^{1}$ are twofold. First, I explain the economics of bank bailouts as distinct from bailouts for other sectors of the economy. Why do all the rules of good competition policy appear to fly out of the window when the banks get into trouble? Does this mean that we should abandon the rules equally for car manufacturers and other industries in trouble? I argue that a unique combination of two characteristics made it essential to bailout or nationalize the banks in the current crisis. No other sector of the economy can claim the same justification. Second, I review the threat of a retreat to politically-determined industrial policy and the need for vigilant implementation of economic effects-based competition policy. 


\section{The Credit Crunch}

The current global economic crisis had its roots in slack economic policy and huge strategic errors by the banks. ${ }^{2}$ Permitted by weak regulation and driven by biased incentives, the banks borrowed (and lent) far too much given their low capital bases, and were caught out when the housing price bubble began to burst, heralding large-scale defaults. The global reach of this behavior was compounded by the sale and purchase of opaque mortgage-backed securities and their derivatives between financial institutions. The banks' recklessness was facilitated by weak corporate governance, ineffective regulation, permissive monetary policy, and massive international flows of funds. ${ }^{3}$ Like unlimited supply of food in the animal kingdom, huge flows of funds into western banks suppressed the power of competition to select only the fittest to survive. Similarly, rapid recession, like periods of limited food, soon picks off the unfit and, if the drought is severe, many of the fit as well.

There have been two enormous market consequences of these events and a third may be round the corner. The first was that many of the THE BANKS' RECKLESSNESS
WAS FACILITATED BY WEAK
CORPORATE GOVERNANCE,
INEFFECTIVE REGULATION,
PERMISSIVE MONETARY POLICY,
AND MASSIVE INTERNATIONAL
FLOWS OF FUNDS. world's most renowned banks have been pushed close to bankruptcy. For some, this was the direct result of their own recklessness, but others have been sucked into the whirlpool. Governments across the world have stepped in to bail them out by guaranteeing loans, injecting capital, underwriting toxic assets, and acquiring their shares. Such has been this commitment that only one bank of major significance has so far gone bust (Lehman Bros). This "success" has been achieved only at huge cost to current and future taxpayers.

The second consequence was contagion into the non-financial sectors of the economy. The banks cut lending in every way they could in order to rebuild their reserves. ${ }^{4}$ This created severe financial constraints for their business and private customers, resulting in investment cuts, reduced demand, and a powerful negative multiplier across the global economy. Beyond financial constraints, consumer and investor confidence were shattered creating a further squeeze on demand. Fearing a Japanese style "lost decade" of deflation and stagnation, governments and monetary authorities have been trying to reverse this by slashing interest rates, buying securities, increasing public spending, and temporarily reducing taxes. Much of this may have been necessary as an emergency measure, even though the haste, panic, and haggling with which such packages were put together suggests many initiatives will have been substantially wasteful.

The third potential consequence could be an interventionist industrial policy in the wider economy and the emasculation of competition policy. Currently, this has happened only to a minor extent, but aspects of rescue packages promoted by governments across the globe point to the danger. In the last decade, com- 
petition policy has been reinvented across Europe ${ }^{5}$ and introduced in many emerging economies with vigor and new focus on economic foundations. This has been a huge success in protecting consumer-responsive markets and efficient business practices. The discipline of competition policy has also allowed the reduction of inefficient forms of regulation and public ownership. While modern competition policy is economically robust, it remains politically fragile and thus vulnerable to crude, populist, deeply-flawed claims that it is an unnecessary luxury in times of recession-or even that the crisis itself is due to "too much competition." A more considered analysis shows this to be untrue, but it is all too easy to see why the mistaken view might take root.

The aims of this paper are twofold. First, I explain the economics of bank bailouts and why they are different from bailouts for other sectors of the economy. Second, I review the threat of a retreat to politically-determined industrial policy and opportunities for the implementation of an active competition policy. Section 2 highlights a unique combination of two characteristics that made it essential to bailout or nationalize banks in the recent crisis. In section 3, I assess the dangers of bailing out failing firms in sectors that do not exhibit both these characteristics. The recent trend in interventions and the positive role of competition policy during the recession are reviewed in section 4 . Section 5 presents a brief conclusion.

\section{Bailouts, Nationalization, and Regulation for Banks $^{6}$}

\section{A. CAUSES}

After years of lecturing and lobbying from the West, China adopted its new Anti-Monopoly Law only last year (2008). China may, therefore, be puzzled to see so much government intervention in banks in recent months, including:

WHY DO ALL THE RULES OF GOOD COMPETITION POLICY APPEAR TO

FLY OUT OF THE WINDOW WHEN THE BANKS GET INTO TROUBLE? massive individualized subsidies, direct "interference" in business decisions, politicians promoting mergers, and nationalization. ${ }^{7}$ Why do all the rules of good competition policy appear to fly out of the window when the banks get into trouble? Does this mean that we should abandon the rules equally for car manufacturers and other firms or industries in trouble? I address the first question in the remainder of this section and the second in section 3 .

All markets have their own idiosyncrasies but each works fundamentally in the same way. Only rarely are the idiosyncrasies so substantial that they warrant special treatment. It is an unfortunate truth that banking is different to other industries due to a unique combination of two essential characteristics that cre- 
ate the potential for systemic economic collapse: contagion within the banking sector and contagion from banks to the entire real economy. Before getting to these twin contagions, note the importance of confidence and potential for panic in banking.

A bank can only survive if everyone is pretty certain that it will survive. It cannot survive a loss of confidence. ${ }^{8}$ Banks necessarily borrow short (i.e. customers can withdraw their money at short notice) and lend long, which means they must rely on funder confidence to keep funds flowing in to support their loan book. Banks lend a multiple of what has been deposited and can do this in normal times because most people leave much of their money in the bank. However, in the absence of full guarantees, individual savers have a great deal to lose if a bank goes bust and very little to gain by keeping their money in a particular bank. Even a rumor of potential failure can result in massive withdrawals and, in the absence of intervention, failure is a self-fulfilling prophesy. This can happen even if a bank's loan book is sound because the bank will not have the liquidity to pay all depositors their money.

The problem moves from liquidity crisis to a much more serious insolvency crisis when loans go bad and the bank has insufficient capital to absorb losses. Depositors could not be paid out even if all the good loans could be called in. The loss of confidence cannot then be soothed. The queues outside Northern Rock in the United Kingdom in September 2007 were an early sign of the fragility of the banking system even when most retail depositors were covered by an explicit government guarantee. Wholesale funds from other banks and international lenders were quantitatively much more important and unguaranteed, and it was these that hemorrhaged from Northern Rock to bring it down. Few other products are so sensitive to confidence. ${ }^{9}$ Nevertheless, banks would not warrant special treatment if this was the end of the story because creditors could simply move their deposits to a rival bank which could consequently increase its loans.

The first truly distinctive characteristic of banking from the competition perspective is that the balance sheet of banks are so interconnected that the collapse of a large bank is contagious and contaminates the whole banking system. To a small extent this is because funders (from small retail depositors to international wholesale funds) wonder which will be the next troubled bank from which they should withdraw their funds. But if the crisis was merely one of confidence, that worry could easily be addressed by the central bank providing liquidity to a bank subject to a run. For relatively small bank failures, when banks have adequate capital and when specific risks and reasons for failure are understood, the banking system is typically quite stable. ${ }^{10}$

Banks in highly developed economies do not fail due to liquidity problems alone, but they are interconnected in more significant ways. Banks lend to each other so if one is unable to repay its debts, that failure creates bad debts the lending bank which, in turn, undermines its solvency (counterparty risk). Before the 
current crisis, most banks had shared a similar belief about continuing asset price rises and they did not diversify the associated risk sufficiently outside the banking system. Instead, they exchanged ever more complex and opaque collateralized debt obligations, most importantly those based on mortgages. The risks stayed within the system.

In August 2007, the banks apparently suddenly noticed the rising mortgage repayment delinquencies and foreclosures as house price inflation tumbled. They stopped lending to each other, justifiably concerned that they could not calculate the risks in their own balance sheets, let alone those of counterparties. The self-inflicted wounds of inadequate capital, bad loans notably in U.S. subprime mortgages, and foolish trading in derivatives spread the damage and destroyed the already limited capital of many banks and related financial institutions. ${ }^{11}$ Like firms in all industries, banks go bust when their capital is exhausted by bad trading but, because of the interconnectivity

LIKE FIRMS IN ALL INDUSTRIES, BANKS GO BUST WHEN THEIR CAPITAL IS EXHAUSTED BY BAD TRADING BUT, BECAUSE OF THE INTERCONNECTIVITY BETWEEN BANKS, BAD LOANS AND BAD ASSETS QUICKLY SPREAD THROUGH THE GLOBAL BANKING SYSTEM. between banks, bad loans and bad assets quickly spread through the global banking system.

The banking crisis lurched towards potential catastrophe a year to the day after those Northern Rock queues on U.K. high streets, when the major U.S. bank Lehman Bros was allowed to collapse and the global financial system nearly followed. In simple economic terms, this first distinctive characteristic is that a large bank with substantial trading activities has a negative externality on its rivals-if it collapses, the stability of its rivals is undermined. ${ }^{12}$ This is in sharp contrast to, say, a grocer or a car manufacturer where others in the industry can usually benefit from the collapse of a rival. ${ }^{13}$

The second distinctive characteristic is that bank finance provides the essential oil in the entire economic system, allowing firms to make investments and to absorb the bumps of fluctuating revenues and payments. In normal times, banks lend to each other for exactly the same reason. Additionally, traditional investment banking puts together funding for bigger projects. Without this oil provided by the banks, the economy seizes up. The product of no other industry is as essential to every other market in the system. Banks are particularly important for smaller firms which do not have the scale to issue corporate bonds and do not have access to the internal capital markets of large business groups. ${ }^{14}$ They are also important for financing large purchases by consumers (e.g. housing, cars). Unfortunately, during a banking crisis, the first reaction of a bank is to stop making loans in order to compensate for its loss of deposits and asset write-offs. If the banks thus fail to fulfill their crucial lending function, this leads to a fall in demand and macroeconomic recession. This is the second dimension of contagion. ${ }^{15}$ 
Thus, the deposit-side of banks is vulnerable to contagion in the withdrawal of funds and especially asset write-downs, and the consequent loan-side collapse contaminates the whole economy as banks try to rebuild their balance sheets. These two characteristics combined into a compelling argument for treating the banks as a special case in the current crisis. The prospect of contagious bank failures justifies intervention both to provide them with liquidity and to keep them solvent. However bitter the taste to taxpayers, this applies even when the banks' plight is their own fault.

This double contagion is unique. A food product may be vulnerable to a health scare and a contagious loss of confidence for that particular product, but this would not result in global recession if it was taken off the supermarket shelves. ${ }^{16}$ Electricity may be required for the production of practically every other product in the economy, but it does not suffer from within-sector contagion-electricity supply did not collapse with Enron and would be little affected by the bankruptcy of a major supplier. Only the banking system combines both of these characteristics to create the potential for genuinely systemic contagion. A detonator alone makes only a small bang, and TNT alone is a relatively stable material, but put the two together and you have a truly dangerous bomb. As it is, the banking crisis detonated a huge bomb under the global economy. The collapse of another major bank could have been nuclear. There was no sensible alternative but to bail out or nationalize failing major banks. ${ }^{17}$

There is one more twist to the story. This spe-

AS IT IS, THE BANKING CRISIS DETONATED A HUGE BOMB

UNDER THE GLOBAL ECONOMY. cialness of banks has been a substantial cause of the crisis. The major banks are now sure of what they already thought they knew: they will always be bailed out. The shock of the Lehman collapse was the exception that only served to prove the government guarantee. The consequences of collapse were seen to be so awful that governments have bailed out the banks ever since.

The anticipation of this bailout had created a moral hazard that biased decisions towards risk taking. The upside for banks was huge potential profits and the downside was a bailout. This asymmetry was reflected in the bonus structure for executives and the traders they employed. The reward for short-term trading success was huge, while there was no equivalent sacrifice for having made losses and no claw-back for short-term profitable trades that turn sour. This system allowed banks to share the same bullish beliefs in asset prices without diversifying the risk outside the banking system. It also encouraged heavy duty lobbying to reduce the effectiveness of regulation. Some banks did remain prudent, but others competed on upside alone. ${ }^{18}$

\section{B. SOLUTIONS}

Having identified some of the problems, what should have been done to solve them? In the short term, the urgency should have been to get banks lending 
again and so to limit the contagion of the banking crisis to the rest of the economy. Most governments tried to do this indirectly by recapitalizing the banks, often in return for some form of preferred stock (i.e. something between a standard loan and common equity). This allowed them to say that a bank was not being nationalized even when the taxpayer became the majority stock holder and took a high risk of not being repaid.

Governments have also provided credit insurance and toxic asset underwriting (ex post i.e. after the assets had turned toxic!) and central banks have purchased large quantities of bonds from the banks. ${ }^{19}$ While this bailout has saved many banks from collapse, it did not get them lending again on a sufficient scale and urgency. These banks have instead used this funding to rebuild their own capital while they operated in the shadow of collapse.

THIS CREATED "ZOMBIE BANKS" WHICH DRAIN FUNDS WHILE FAILING TO FULFILL THEIR RAISON D'ÊTRE. This created "zombie banks" which drain funds while failing to fulfill their raison d'être.

Government loan guarantees have also failed to stimulate lending on a significant scale. Unfortunately, against this limited success, the bailouts will further reinforce the asymmetry in risk-taking by banks once more normal times return. Meanwhile, the banks' self-preservation measures made the recession bite harder, thus "justifying" their failure to lend to businesses by claiming that those businesses have become too risky.

There would have been less contagion into the real economy if a form of temporary nationalization (beyond passive ownership of preference shares) had been adopted early in the crisis. The idea would be for those banks which were nationalized to be run by trustees and concentrate on traditional lending based on investment and repayment prospects. It would draw on the traditional skills and expertise of bankers in assessing loans and creditworthiness, but importantly should not undercut terms provided by private lenders in normal times. Their loans would be made on full commercial terms and such banks would be privatized as soon as economic conditions permitted.

Had such nationalization been adopted in late 2008, this would have limited the contagion into the real sector. ${ }^{20}$ Competition authorities could have been instructed to monitor that each nationalized bank was indeed operating on genuine commercial terms both in attracting funds and in lending activities. ${ }^{21}$

There are major problems with such a strategy both in the process of nationalization and in the State running a commercial bank. Nationalization of a bank that would be bankrupt in the absence of government help would, quite fairly and efficiently, wipe out the common shareholders and reduce the payout for junior creditors. It would probably also cause shareholders and subordinated creditors of some other banks to flee in anticipation of nationalization. This means that several major but weak banks would have to be nationalized simulta- 
neously. This would undoubtedly be politically uncomfortable. Since pension and insurance funds also invest in banks, the spillover could be far-reaching and the state may have to absorb some of the creditor losses to keep otherwise wellmanaged insurance companies afloat. However, there is no reason to provide such insurance to shareholders in general.

It has to be acknowledged that the aim of a nationalized bank to make loans only on commercial terms has limited credibility because politicians are genetically prone to fiddling with any high profile asset they own. This certainly happens under long-term state ownership but not necessarily over the short term. This problem must be balanced against the prospect of "standard" bailouts creating zombie banks that are not lending and so causing a protracted recession. ${ }^{22}$ As soon as the economy recovers and an appropriate regulatory regime has been established, these banks should be privatized, though in a restructured form to minimize the risk of future contagious bank failures.

These rapidly privatized banks should probaIT HAS TO BE ACKNOWLEDGED
THAT THE AIM OF A
NATIONALIZED BANK TO MAKE
LOANS ONLY ON COMMERCIAL
TERMS HAS LIMITED CREDIBILITY
BECAUSE POLITICIANS
ARE GENETICALLY PRONE TO
FIDDLING WITH ANY HIGH
PROFILE ASSET THEY OWN. bly be much smaller than the ones that failed, and so less prone to causing future systemic collapse. This would help to balance the sharp increase in bank concentration that has been a consequence of the crisis. For example, in the United States, we have seen the consolidation of: Bank of America, Countrywide, and Merrill Lynch; JP Morgan, Washington Mutual and Bear Stearns; Wells Fargo and Wachovia. In the United Kingdom: Lloyds TSB and HBoS; Santander and Bradford \& Bingley; Nationwide and Dunfermline; ${ }^{23}$ while Northern Rock has been the only conventional nationalization. Internationally, Lehman assets were picked up by Barclays (United Kingdom and United States) and Nomura (Asia). No one can seriously claim that this change in banking market structure has been due to the natural market forces that should rightly shape an efficient market structure.

In the medium term, major revisions of bank regulation are necessary so that banks can compete as private firms with balanced incentives. Financial markets are not unique in having special features that require a specific regulatory framework to align competition and welfare. For example, some industries (e.g. infrastructure networks distributing electricity, water, or rail services) are subject to such strong economies of scale that they are natural monopolies and so require a specialist regulator to control maximum prices; but banks do not have such strong scale or network economies to make them anywhere near natural monopolies.

A more relevant example is pharmaceuticals, for which there are powerful health and safety reasons to regulate new drugs. In late 1950s Europe, this regulation was entirely insufficient, with the result that thalidomide was prescribed 
to pregnant women. The resultant tragedy brought about a new and necessary regulatory approval regime, subject to which pharmaceutical companies can compete with each other. ${ }^{24}$ It is essential that the current crisis should similarly bring about more effective and appropriate financial regulation while still encouraging beneficial competition and innovation.

An international regulatory system already existed pre-crisis with a view to setting minimum standards for banks and so to channeling competition into appropriate behavior. This took the form of the agreement known as Basel II, which has three "pillars:" minimum capital requirements, regulatory supervision, and risk disclosure to facilitate market discipline. ${ }^{25}$ Clearly, the application of this framework has proved inadequate in the face of complex financial innovations and distorted incentives.

The following elements of regulation are additional to a necessary review of the standard components of Basel II. ${ }^{26}$ First, incentives given to individuals with-

Recent European Debate

HAS BEEN SIDE-TRACKED

INTO CRUDE PROPOSALS TO

LIMIT THE SCALE OF BONUSES,

WHEREAS IT IS THEIR INCENTIVE

EFFECT THAT IS CRUCIAL. in banks must not be one-sided (i.e. paying bonuses for short-term profit with no downside for long-term losses). Recent European debate has been side-tracked into crude proposals to limit the scale of bonuses, whereas it is their incentive effect that is crucial.

Second, while credit default swaps and other elements of diversification and insurance must be allowed as prudent trading activities, they should not be traded by banks multiple times as bets on future prices or defaults. ${ }^{27}$ Liquid markets also need to be created to get genuine prices for all supposedly safe assets.

Third, banks should be charged ex ante (i.e. before they get into a mess) for the explicit (and implicit) guarantees they receive from government, and the size of these charges should reflect the risk profile chosen by each particular bank, including the amount of debt financing relative to its equity base. ${ }^{28}$

Fourth, idiosyncratic assets, collateralized debt obligations ("CDOs"), and other complex or opaque financial innovations might be required to pass regulatory scrutiny and receive positive approval from a regulatory body, and not from a credit rating agency which is beholden to issuers for fees and supplementary services. ${ }^{29}$ Credit ratings could be privatized at a later date once an appropriate regulatory regime is established.

Finally, and arguably most important, a credible bankruptcy regime must be established for banks so that contagion is contained. This is likely to require preemptive action by a monitoring central bank (and not the daily regulator which may be reluctant to admit that it has failed to keep the bank on track). 
In conclusion, the banking system combines the two explosive characteristics of contagious failures and universal need by every other business. This combination means that major banks cannot be allowed to fail. The risk this entails and the recklessness it encourages mean that tough prudential regulation is essential. This is all the more important because recent bailouts only reinforce the moral hazard.

However, it is important to regulate appropriately so as not to stifle competition and innovation. This requires targeting regulation clearly at the problems (e.g. externalities, distorted incentives) and not a knee-jerk political response against the wrong target (e.g. competition, securities to diversify risks). With appropriate regulation and the standard tools of competition policy in place, competition among private banks can be left to work to the benefit of efficient businesses and consumers. The appropriate regulatory framework is necessary to align competition and welfare, bringing sustainably low prices for banking services and safe, innovative product development.

Finally, there is no reason why a government should not use their 'bailout' stakes in banks to restructure them into less contagion-prone (probably smaller) institutions. In Europe, the Commission is likely to use its state aid powers to require some degree of restructuring, but it remains to be seen whether this will be designed as an ad hoc punishment or a genuine attempt to redress properly identified problems.

\section{Competition Versus Bailouts for the Rest of the Economy}

The banking crisis stifled lending and the consequent credit crunch triggered a global recession. Minor banking crises do not always bite on the real economy, but history tells us that when a banking crisis does bite, it bites the economy's leg off. We are very much in the latter category today. A comprehensive IMF study of all systemically important banking crises for the period 1970 to 2007 covering 42 crises in 37 countries shows the average fiscal costs of crisis management to be 13 percent GDP, though they can be as high as 55 percent. ${ }^{30}$ The consequent recessions are even more damaging with average cumulative losses equivalent to 20 percent GDP in the first four years, but ranging from 0-98percent GDP. ${ }^{31}$

It is from this perspective that we must view the massive fiscal stimuli that many governments put in place as an attempt to limit the decline and shorten the period of stagnation. The size of required fiscal stimulus could have been much less if bank finance was working properly. Even on an optimistic scenario, however, there will be a deep and protracted recession that is seeing numerous firms fighting for their survival. In these circumstances, should we abandon competition policy, particularly as it relates to state aid? I consider only aid to specif- 
ic firms or industries, and not general fiscal or employment measures that are reasonably neutral in their impact on competition. ${ }^{32}$

Competitive markets certainly work to the benefit of consumers and efficient firms when financial markets are oiling them well. In good times, firms expand and enter new markets as they seek to attract customers and spending away from rivals. Profits are made by those who have invested well, produce efficiently, and make the most attractive product offers (i.e. those who provide what consumers want at a better price than offered by rivals). In bad times, firms contract and leave the market as they adjust to reduced customer spending. Losses are made by those who fail to provide what their customers want or who set prices that are too high (i.e. those who make unattractive offers).

Firms with the least attractive products or highest costs exit the market. Exit is as fundamental as entry in making markets work well. It is part of natural selection, leaving room for efficient firms to expand and new firms to enter. The same essential story applies to shops, restaurants, steel and cars. The role of competition policy is to ensure that firms do not conspire to evade this harsh but socially productive competitive discipline by fixing prices, excluding efficient rivals, merging with significant competitors, or receiving discriminatory state subsidies or protection.

In the absence of the special features discussed in section 2, subsidies undermine market outcomes and processes. ${ }^{33}$ The problem most familiar to the European debate on State aid is that subsidies create international distortions to competition. Inefficient firms receiving subsidies take market share from more efficient foreign suppliers. This can result in

THE PROBLEM MOST FAMILIAR

TO THE EUROPEAN DEBATE ON

STATE AID IS THAT SUBSIDIES

CREATE INTERNATIONAL

DISTORTIONS TO COMPETITION. retaliation and a mutually destructive subsidy war funded by taxpayers.

However, the problems are not only international. Subsidies undermine the market mechanism because the prospect of a bailout leads to reckless behavior, as is so vividly illustrated by the banks. It also leads to "rent seeking" as the most successful CEOs become those who can best work the political system for subsidies, and not those who efficiently produce the best and most innovative products. There is abundant evidence of the failure of politicians or civil servants to pick winners. More insidiously, there is also a negative effect on efficient firms and entrants who are incentivized to hold back on investment and aggressive marketing if they know that inefficient rivals will hang on to segments of the market with inappropriate product offers and bloated capacity without fear of the consequences.

In structurally competitive industries (i.e. in the absence of sunk costs, state subsidies, or entry barriers), entry into and exit from a market can rapidly adjust to demand changes. Firms respond to expected prices relative to average costs to 
trigger entry and exit. Incentives change in the presence of sunk (i.e. non-recoverable) costs; for example, not only will they want to stay in the market as long as variable (non-sunk) costs are covered, but they may want to hang on even if price falls below these costs as long as there is a prospect of the market recovering. ${ }^{34}$ Thus, firms will be more cautious to enter and slower to exit. This provides a natural balance for such markets with less entry when demand is high and less exit in recession. Profits in good times balance losses in bad times and properly working financial markets will appreciate this and provide the necessary financial buffer.

Both economic theory and most of the empirical evidence suggest that an unhindered exit process is at least reasonably efficient. ${ }^{35}$ The research shows that in the absence of intervention the market selects the best adapted firms to survive. The least efficient plants exit first, including those too small to achieve available economies of scale. If firms are equally efficient, then the largest downsize first. Once these adjustments have been made, if demand is insufficient relative to economies of scale and the toughness of competition, there may be a period

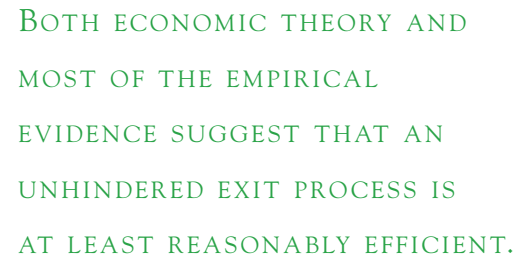
of attrition with prices below cost until one of the remaining firms exits. This is a painful process for all in the industry and the transaction costs are substantial but it has the desirable attribute of leaving a sustainably efficient and competitive market structure. ${ }^{36}$

How do things change when financial markets fail to provide lubrication and instead throw grit into the economic system? Problems can be caused at two levels. First, banks and other providers of finance play a vital role in appraising investment projects and the long-term viability of firms. It is possible that arbitrary financial constraints due to the banking crisis might force the exit of a firm that serves consumers better than a rival; yet the inefficient rival might survive because it happens to have a stronger line of credit. ${ }^{37}$ Second, financial constraints on customers may depress demand for a whole sector if purchases are widely funded by borrowing (e.g. construction, cars, machinery), which might result in the scrapping of skills and assets that would be productive once the credit crunch clears.

These possibilities only serve to emphasize the need to get banks lending. As argued earlier, recapitalizations and loan guarantees have proved expensive yet insufficient to indirectly get the banks to lend. It would have been better had the governments taken active control of those banks they are subsidizing. These banks could have been run by independent trustees for the duration of the recession and with a policy of lending on "market investor" unsubsidized terms. ${ }^{38}$ The idea is to correct the cause of the problem, the credit crunch, and to avoid giving politically determined subsidies to specific firms or industries. The resultant 
loan book would then be attractive when the bank is privatized as soon as the market conditions allow.

There are two highly unattractive alternatives. Either no intervention, so competition is distorted and firms reliant on bank funding are affected asymmetrically, or finance determined by the "Department for Industry" where firms will be helped according to political impact and not according to previous reliance on bank funding. ${ }^{39}$ The key lending skills lie within the banking sector whereas government departments find an easy route through grand gestures to big firms and big industries (even if the recipients were in long-term decline pre credit crunch).

With appropriate measures to get banks lending, are some "real sector" firms still "too big to fail" in a recession? "Too big" may be interpreted in several ways. The firm might be a monopoly provider, a large direct employer, or a firm supporting a large supply chain or distribution network. For a monopoly provider such as the owner of a rail network or a vital tunnel, the asset does not disappear if the owner gets in financial difficulty. If the assets have any positive value they can be bought out of administration and operated under new ownership. If the firm is not a monopoly but a large employer, then its viable assets could also be bought out of administration. It is inefficient to subsidize current shareholders and it would be harmful if it received preferen-

WITH APPROPRIATE MEASURES TO

GET BANKS LENDING, ARE SOME

“REAL SECTOR” FIRMS STILL “TOO

BIG TO FAIL” IN A RECESSION? tial treatment over an efficient rival. The same argument applies to a long supply chain in, for example, the car industry.

More subtly, it is possible that an efficient and an inefficient manufacturer may share key suppliers who benefit from economies of scale. The loss of a major customer may put such suppliers at risk and so potentially harm the efficient manufacturer's supply chain. However, an efficient supplier can respond by expanding into the market opportunities created by the exit of the inefficient firm and scaling down. ${ }^{40}$ This is the way markets work to select efficient producers and subsidies interfere with this process. Subsidies to support a whole industry may appear less distortionary, but they inevitably divert demand and resources away from substitute products and so shift the pain. No other sector of the economy shares the pair of characteristics that set banks apart for state intervention in the current crisis. ${ }^{41}$

There is no doubt that restructuring is painful. However, the pain is less than the harm caused by industrial subsidies, as experienced by: efficient rivals who suffer reduced market share; customers who are offered costly and unattractive products; taxpayers whose real income falls; or the elderly, the sick, and school children who suffer from diverted public spending. It is important that those thrown out of work should receive strong support both financially and in retraining, but it is they who should receive the subsidies and not the shareholders and senior executives of failing firms. It is the latter who benefit most from bailouts. 


\section{The Positive Role for Competition Policy During the Recession}

Most of the analysis so far has related to State aid because this is the competition policy front line in a recession. History provides some worrying lessons also for other dimensions of competition policy. Anticompetitive agreements and mergers cause long-term harm which gets discounted heavily in a crisis. In international trade policy, there is a well known and strong correlation between recession and protection, with causation going both ways and feeding a negative spiral. ${ }^{42}$ Effective enforcement of national competition policy in most of the world is relatively recent, so has yet to be challenged by recession. However, the United States has had the Sherman Act since 1890 and the last 120 years have seen numerous wars and slumps. Both types of crisis have dampened enforcement of the Act and the consequences have been particularly bad during recessions. Business cooperation can be bought (superficially cheaply) by politicians: "Antitrust laxity is often the government's first bargaining chip when it urgently needs something from industry." ${ }^{43}$

Much has been made of the similarities between the current crisis and the Great Depression, especially the fiscal role of the New Deal. A closer look, however, does not settle

BUSINESS COOPERATION CAN BE BOUGHT (SUPERFICIALLY CHEAPLY) BY POLITICIANS: "Antitrust laxity is often THE GOVERNMENT'S FIRST BARGAINING CHIP WHEN IT URGENTLY NEEDS SOMETHING FROM INDUSTRY." one's nerves. ${ }^{44}$ Franklin D. Roosevelt was persuaded by industrialists that it was necessary to suppress the enforcement of competition policy to gain cooperation and he agreed to this as an integral part of the deal. In twelve months from June 1935, the Interior Department received identical bids from steel firms on 257 different occasions, and these bids were 50 percent higher than foreign steel prices. It has been estimated that wholesale prices in 1935 were 24 percent higher than they should have been and even by 1939 they remained 14 percent higher. Cartel prices fed through to unrealistic wages and Cole \& Ohanian estimate that unemployment was 25 percent higher than it would have been otherwise. They suggest that the depression may have lasted seven years longer than necessary. ${ }^{45}$

Fortunately, international institutions facilitating political and economic dialogue are now well established and genuinely global (e.g. WTO, G20), as has been made necessary by global economic integration. This has undoubtedly helped with the initial responses and rhetoric of policy intervention. However, there are dangerous signs. In the United Kingdom in October 2008, the Office of Fair Trading ("OFT") recommended that the Competition Commission should investigate the proposed merger of Lloyds-TSB and HBOS, but this advice was overridden by the Secretary of State. ${ }^{46}$ This was the first case of such an intervention since the reforming Enterprise Act of 2002 was meant to take 
mergers out of political decision making. ${ }^{47}$ The merger has turned out to be a financial disaster and the interventions discussed in section 2 would undoubtedly have been better. As it stands, the United Kingdom (like the United States) now has a more concentrated banking structure which will be even more vulnerable to systemic failure unless prudential regulation is very much improved.

In spring 2009, politicians across the globe were thinking loudly about subsidizing specific firms, particularly in the car industry. The U.S. administration offered major subsidies to General Motors and Chrysler, though in the end not enough to stop them filing for bankruptcy protection. In France, President Sarkozy offered 6 billion EUROs in government support for Renault and Peugeot-Citroen subject to two conditions-no factories located in France would be closed and reassurance regarding jobs in France-before the European Commission intervened. Italy and Spain also produced major car subsidy plans. Intervention then switched to apparently more neutral car scrappage schemes to stimulate demand (though this is still biased towards the car sector and is a costly way of bringing forward the purchase of a durable good at the expense of lower demand next year).

More widely, the traditional instruments of trade protection are also visible. For example, tariffs were raised in India on some steel products, in Russia on cars, and in Ecuador on 940 different products. The EC re-introduced subsidies for the export of milk and milk products. Most of these at least work within WTO rules (e.g. raising tariffs within legal limits) but it remains likely that anti-dumping duties will return as a battleground: 2008 saw a 28 percent rise in applications over the previous year, the first rise since 2001.

National procurement has also been tied to fiscal policy. The February 2009 $\$ 800$ billion fiscal stimulus bill of the new Obama administration included "Buy American" clauses (e.g. for steel to be used in state projects), though the original plan was modified in the face of potential retaliatory action by the EU. Paul Krugman has argued that, in the absence of an internationally coordinated fiscal stimulus, these clauses may not be protectionist in that they need not reduce trade below the viable alternative. As he puts it: "My fiscal stimulus helps your economy by increasing your exports - but you don't share in my addition to government debt." ${ }^{48} \mathrm{He}$ continues that if all countries were adopting a similar fiscal stance, "Buy American" would be unnecessary, but as they are not, it might be a second best way to get the economy moving. This is a coherent argument but it is politically impossible to limit the procurement bias to the appropriate level. The danger is that a sequence of "special cases" will result in a flood (which is why it is important to understand precisely why the precedent of the banks is so inappropriate for other sectors).

It is difficult to prevent discriminatory interventions even within the EU. Article 87 of the European Treaty prohibits state aid that may distort trade between Member States but permits non-distortionary forms of aid. For example, 
the Commission requires that aid to banks should be: non-discriminatory, priced according to market investor principles, ${ }^{49}$ and subject to behavioral restraints against aggressive growth at the expense of non-subsidized banks. ${ }^{50}$ The last needs interpreting carefully in the context of banks failing to make sufficient loans (see section 2).

The EC has also invoked Article 87(3)(b) of the EC Treaty, which permits further, but strictly limited, aid intended to remedy a serious disturbance in the economy of a Member State. In December 2008, it adopted a "temporary framework" to allow Member States to tackle the effects of the credit crunch on the real economy in a minimally distortive way. ${ }^{51}$ One aim was to restrict aid only to firms in difficulty due to the financial crisis and not allow aid for firms in long-term decline..$^{52}$ The EC rules are aimed at keeping the playing field level internationally within Europe. They are imperfectly adhered to, but they provide a helpful model for national rules in the current crisis. ${ }^{53}$

As a supranational organization, the $\mathrm{EU}$ is as tight and powerful as international cooperation comes, and it is backed by the legal force of a strong treaty, yet it still has difficulty keeping its members in line. The global institution charged with reducing impediments to international trade, the World Trade Organization ("WTO"), has far less control over its membership and has a very limited mandate. ${ }^{54}$ Nevertheless, it can have a significant reporting role for changes in national trade policies, it can host talks to resolve disputes, and it can speak especially for those developing countries that have little retaliatory power in negotiations. ${ }^{55}$ The lack of powers over sovereign states means that if diplomacy fails, the only credible bargaining chip is retaliatory tariffs or subsidies. Of course, actual trade wars are mutually destructive and the aim is that governments will realize this so the threat does not have to be implemented. By late summer 2009, it seems that, following the initial panic, the political urge for protectionist measures has moderated.

Pressure on the mainstream implementation of antitrust and merger policy comes both from short-term crisis management and, more insidiously, in an urban myth that "too much competition" may have contributed to the crisis. In earlier sections, I have given examples of crisis mergers and also rehearsed the long-term benefits of a competitive economy. As the discussion of bank regulation should make clear, the latter does not mean completely laissez-faire capitalism, but regulation targeted at allowing competition to thrive without creating negative externalities. Recession will create challenges for competition policy in each of the traditional areas: ${ }^{56}$ 
- Agreements between firms: "Crisis cartels" are liable to form when prices drop, and such coordination becomes addictive. ${ }^{57}$ Seductive excuses may emerge along the lines of fixing prices in order to protect the number of post-recession suppliers. However, such cartels are more likely to delay recovery and fossilize an inefficient market structure. Firms in an industry may also try to get together to agree an "ordered reduction in capacity." Such cartels have occasionally been allowed in Europe under Article 81(3) in the past, but this would be misguided as collusion is unlikely to select the most efficient market structure (see section 3). ${ }^{58}$ A potential problem relates to fines for prosecuted cartels because an otherwise appropriate fine might push a cartel member into bankruptcy during a financial crisis. If fines are not adjusted down, this may result in fewer firms in the market. However, this possibility should not be overplayed. Fines are generally set at a level that is insufficient for optimal deterrence because they often do not even cover the profits generated by cartels, let alone take proper account of the low probability of detection. ${ }^{59}$ Cartels also allow inefficient firms to survive in the market. Overall, it is likely to be undesirably anticompetitive to adjust fines down in times of recession.

- Abuse by a single firm: There is a potential danger of a financially strong firm taking the opportunity to foreclose a smaller or more financially constrained rival. Recession, especially one induced by financial crisis, may prove fertile ground for unfair means to tip a rival over the edge. Competition authorities must be alert to such foreclosure though they should not simply protect inefficient rivals. Low demand growth may also facilitate entry deterrence strategies. For some foreclosure problems, the appropriate remedy may be to require access to a key facility or technology. The terms of such access are then crucial to making the remedy effective. Should the current recession result in deflation, that could create problems for previously agreed access terms.

- Mergers: The failing firm defense has been applied, at least implicitly, for bank takeovers in the last year, though there have been fewer such merger justifications in the real sector. If a firm is clearly going bankrupt, and if a particular merger is the least anticompetitive way to ensure the survival of efficient resources in the industry, then such mergers should be allowed. ${ }^{60}$ But this is simply a statement of sensible policy in any circumstances and there is nothing special about the current recession in this respect. ${ }^{61}$ It is only the frequency of this argument that may test the authorities. For mergers that do not involve a failing firm, divestiture remedies may be made more difficult if appropriate buyers cannot be found due to financial constraints. Should this arise, the fallback option has to be full prohibition at least pending the emergence of viable buyers. ${ }^{62}$ There may also be a rise in opportunistic merger proposals with little economic logic but motivated by differential access to finance and an anticipated rise in the stock market. There is no particular reason why such mergers should raise com- 
petition concerns. Finally, the economic justification of declining demand and low margins may be offered to justify the need for a more concentrated "equilibrium" market structure brought about by a horizontal merger, but merger control should focus on expected demand and not be transfixed by the last twelve months in appraising any competition concerns.

\section{Conclusion}

History suggests that competition policy will be increasingly under threat as the recession bites. Businesses under pressure will draw a plausible, though inappropriate, analogy between their own industry and banking bailouts. Those already in trouble before the crisis will grab at the opportunity to plead their case. Politicians seeking short-run popularity will think it is little sacrifice to cast aside the long-term benefits of competition to bribe businesses to support their pet schemes. And if the backlash against selfish, reckless bankers gets confused with the democratic benefits of competitive markets, it may even become tempting for politicians to knock competition policy directly as a populist gesture towards centralized industrial policy. ${ }^{63}$

Careful analysis of the sources of the crisis and a clear understanding of the unique double contagion in banking are crucial prerequisites for developing appropriate policy responses. Certainly, taxpayer money was needed to put the financial system on life support until it can pump sufficient finance on its own. Tighter prudential regulation of banks is self-evidently necessary. I have further argued that it would have been quicker, more direct, and less costly early in the crisis to nationalize troubled banks and instruct them to lend on commercial terms before contagion into the real economy got out of hand. However, no other sector of the economy justifies such exceptional treatment and it would be a great mistake to go backwards to replace competition policy with interventionist industrial policy. Similarly, it would be a mistake to impose regulation beyond that necessary to reduce the likelihood of a future financial crisis.

A strong and active competition policy, including tight control of state aid, ensures that business energies are naturally guided into satis-

A STRONG AND ACTIVE COMPETITION POLICY, INCLUDING TIGHT CONTROL OF STATE AID, ENSURES THAT BUSINESS ENERGIES ARE NATURALLY GUIDED INTO SATISFYING CONSUMER NEEDS AND ARE NOT DIVERTED INTO COZYING UP TO BUSINESS RIVALS OR LOBBYING POLITICIANS. fying consumer needs and are not diverted into cozying up to business rivals or lobbying politicians. It has taken many years for enough politicians to appreciate this. In most countries outside the United States, competition policy of sufficient force has only begun to take root over the last decade. This makes it politically 
fragile and the misleading "precedent" of bailing out the banks must not be allowed to make competition policy another casualty of the crisis.

1 The support of the Economic and Social Research Council is gratefully acknowledged. This paper has benefitted greatly from comments by Jayne Almond, Rob Anderson, Steve Davies, John Fingleton, Alan Gregory, Gerald Gregory, Shaun Hargreaves Heap, John Kay, John Kwoka, Phil Strahan, and from seminar and workshop participants at BERR (now BIS), CCP, UK Competition Commission, WTO, and the International Industrial Organization Society Conference in Boston. None of them can be held responsible for the views I express.

2 This is a revised version of CCP Working Paper 09-04 which was written in early March 2009. I still refer to the "current crisis" although there are signs in late summer 2009 that the worst of the "crisis" may be over. The consequent recession, unemployment, and government indebtedness will have repercussions for many years to come.

3 These flows were mainly from Japan and developing economies with trade surpluses (notably China and oil exporters) into the most financially developed countries (notably the United States and United Kingdom) seeking a safe haven for their savings and a place to hold reserves to counter possible future exchange rate crises. John Taylor makes the case that slack monetary policy, especially during 2003-05, and inappropriate policy responses to the evolving crisis should bear substantial blame; see John Taylor, The financial crisis and the policy response: an empirical analysis of what went wrong, (November 2008, mimeo).

4 Symptomatically, the banks were much more reluctant to cut their own bonuses unless required by governments to do so.

5 See the introductory chapter in Bruce Lyons (Ed.), CAses in European Competition Policy: the EConomic ANALYSIS, (2009), CUP.

6 I use the word "banks" as shorthand for all financial institutions that intermediate and insure transactions by firms and consumers.

7 For example, by February 16, 2009, the current crisis had seen the European Commission approve 43 separate financial sector aid schemes by Member States, and was investigating 11 more. These covered 19 Members including all 15 who joined pre-2004. See EC MEMO/09/67.

8 See John Vickers, The financial crisis and competition policy: some economics, GCP MAGAZINE (December 2008), available online at www.globalcompetitionpolicy.org.

9 Confidence can also be important for firms whose purchasers do not receive the full benefit of the product at the time of purchase (e.g. insurance, airline tickets booked in advance, warranties, network products).

10 For example, see: Joseph Aharony \& Itzhak Swary, Additional evidence on the information-base contagion effects of bank failures, J. BAnking \& Fin, 20, 57-69 (1996); Aigbe Akhigbe \& Jeff Madura, Why do contagion effects vary among bank failures? J. BAnKING \& Fin, 25, 657-80 (2001); Bong-Chan Kho, Dong Lee \& Rene Stulz, US banks, crises and bailouts: from Mexico to LTCM, AM. ECoN. R. P\&P, 90.2, 28-31 (2000).

11 See Lawrence J. White, Financial regulation and the current crisis: a guide for the antitrust communi$t y$, American Antitrust Institute working paper (2009) for an informed account of institutional problems in the U.S. mortgage system. His Table 5 shows that the 15 largest U.S. financial institutions each had equity (own capital) of less than 10 percent of assets. Such high leverage meant that an acrossthe-board fall in asset values of 10 percent would have moved each of them into negative net worth. 
12 White (2009), Id, develops some differences between: a "small bank" which can relatively easily be saved by a central bank and its good assets sold to another bank; and a "large bank" that has more uninsured deposits and securities, much higher exposure to derivatives, and is a source of substantial counterparty risk.

13 If a supermarket goes bust, its rivals shed few tears as they bid to buy productive assets from the administrator and seek to supply the bankrupt chain's former customers. I return to the case of car manufacturers in section 3 .

14 Empirical evidence for U.K. firms is provided by a series of surveys of SMEs conducted for the Department for Business, Innovation and Skills, published as Business Barometer (April 2009, URN 09/P75C). Although the successive samples of SMEs are not strictly comparable, the trend in responses is worrying because the percentage of SMEs unable to obtain finance from the first bank approached has increased sharply. In December 2008, it was 33 percent, up from 14 percent a year earlier. By April 2009, the figure had risen to 41 percent. The main reason given by refusing banks to SMEs was that their business sector was too risky. Needless to say, this is a self-fulfilling prophecy. Second most frequently mentioned was insufficient collateral (also self-fulfilling as property prices decline with the withdrawl of mortgage finance). For a related theoretical analysis of the advantage to larger firms, see Xavier Boutin, Giacinta Cestone, Chiara Fumagalli, Giovanni Pica \& Nicolas Serrano-Velarde, The deep pocket effect of internal capital markets, CEPR Discussion Paper 7184, (2009).

15 Even in more normal times, the role of banks in mobilizing savings and allocating investment funds means that an appropriately competitive banking system is, in turn, crucial for developing the structure and competitiveness of other markets in the economy. For reviews of competition in banking, see: Allen Berger, Asli Demirguc-Kunt, Ross Levine \& Joseph Haubrich, Bank concentration and competition: an evolution in the making, J. Money, CRedIT AND BANKING, Vol.36.3 (Part 2) pp.433-451 (2004); Stijn Claessens Competition in the financial sector: overview of competition policies, IMF Working Paper 09/45; Xavier Vives, Competition in the changing world of banking, OXford R. ECON. PoL'Y, No.17, pp.535-45, (2001).

16 In normal financial times, a firm whose product is not contaminated (or which can be swiftly made safe) will be able to obtain a loan to tide it over until the scare subsides. Banks cannot provide this service to themselves.

17 This is despite the huge costs. The principal bailout schemes in the EU totaled a nominal EURO 3 trillion, which is 24 percent EU GDP. However, three-quarters of this has been in guarantees, most of which will not be called in, and 10 percent was capital injections, some of which have increased in value. Recession due to contagion into the real sector will almost certainly be more costly in the long run.

18 Excessively risky activities included exposures to complex securitizations, trading of derivatives, and off-balance sheet activities that undermined capital adequacy. In particular, CDOs based on mortgages have been central to the failure of banks in the current crisis; and multiple trading of credit default swaps also created problems as the economic crisis deepened and firms became unable to repay loans. Problems were multiplied by ratings agencies wrongly attributing AAA status to these complex derivatives despite the absence of market prices (they had to rely on highly complex, fragile computer models). Furthermore, these CDOs often stayed within the banking system unsafely hidden off-balance sheet in structured investment vehicles ("SIVs"). The cavalier attitude to risk was not only found in U.S. and U.K. banks developing "innovative" financial products. For example, Austrian banks lent excessively to Eastern European consumers and firms and Japanese banks bought corporate equities. Weak corporate governance of banks played an important role in allowing this.

19 The latter is part of a monetary policy of "quantitative easing" (in the United Kingdom, United States, and several other countries) but it still supports the banks by providing liquidity. 
20 Nationalization would also have permitted clearing out the senior executives of failed banks without undeserved compensation packages.

21 The EC does this routinely for state aid cases, and the OFT fulfilled this monitoring function with Northern Rock during its first year in public ownership. See Office of Fair Trading, Northern Rock: the impact of public support on competition, OFT1068, (March 2009).

22 This was a feature of the Japanese economy in the "lost years" of the 1990s.

23 Nationwide was paid $\mathrm{f1.6}$ billion by the government to take over Dunfermline. Both were building societies.

24 It has to be acknowledged that the nature of pharmaceuticals customers, particularly national health authorities and price regulators, creates a tangle through which competition policy must operate in most countries; see Stephen Davies \& Bruce Lyons Mergers and Merger Remedies in the EU, EDWARD Elgar, Ch. 8 and 9 (2007) for a discussion of competition and merger control in pharmaceuticals markets.

25 Basel II was agreed in 2004 and modified in 2005, so in principle it should have been up-to-date with modern banking. There are lessons to be learned about regulatory complexity and delegated responsibilities.

26 A core element of these standard components is Tier 1 asset requirements. These should be strengthened and made less pro-cyclical (the current fixed ratios mean that, in a recession, capital gets written off, which means loans must be reduced, which deepens recession). Also, the value of assets at risk needs to take account of apparently improbable severe crises (sometimes known as the "fat tails" problem in the distribution of returns). Consideration might also be given to limiting loan sizes relative to asset value, if this can be shown to contribute to asset price bubbles. For more macroeconomic suggestions, see Mathias Dewatripont, Xavier Freixas, \& Richard Portes [eds.] Macroeconomic Stability and Financial Regulation: Key Issues for the G20, CEPR, (2009).

27 This distinction between diversifying risk and simply betting on markets is often confused. A related confusion is over investment banking which in recent years has been increasingly associated with trading activities (as distinct from project funding). There are good reasons to join retail and traditional investment banking and to trade securities for the specific purpose of diversifying risk. However, given the necessity of taxpayer bailouts of failing banks, there are very good reasons to separate huge trading (i.e. betting) activities which certainly do not justify being underwritten by the taxpayer but which seem to have grown to dominate "investment banking." This should be the context for the reintroduction of an appropriately modified Glass-Steagall Act.

28 Viral Acharya \& Julian Franks, Capital budgeting at banks: the role of government guarantees, OXERA AGENDA (February 2009) argue that government guarantees of bank survival have driven the cost of debt finance down to risk-free levels, which has encouraged excessive leverage.

29 Unfortunately, banks cannot be trusted to assess their own strategic risks. Paul Moore, former head of group regulatory risk at $\mathrm{HBOS}$ was dismissed (with a reputed $£ 0.5 \mathrm{~m}$ gagging payment) for pointing out in 2003 and 2004 that the bank was taking on too much risk in relation to excessive growth in lending (evidence to the House of Commons Treasury Committee; February 10, 2009). It is unlikely that this overruling of risk managers was unique to HBOS or to concern over lending growth. The Icelandic bank Kaupthing, Singer \& Friedlander dismissed its heads of both risk and compliance when they complained about risky practices (Channel 4 News, February 24, 2009). In both the HBOS and Kaupthing cases, the concerns were also reported to the FSA (the U.K. financial regulator) but neither bank was reprimanded. In 2003, Ron den Braber warned his bosses at RBS that their models were underestimating risk (FINANCIAL TIMES, March 10, 2009). Other similar, sometimes anonymous, stories have been reported in newspapers in relation to excessive risks in the trading of complex derivatives (e.g. SUNDAY TIMES, February 22, 2009). The systemic problem is a failure to balance upside risk with the downside. 
30 Luc Laeven \& Fabian Valencia, Systemic Banking Crises: A New Database, IMF Working Paper WP/08/224, (2008).

31 John Boyd, Sungkyu Kwak, \& Bruce Smith, The real output losses associated with modern banking crises, J. MoneY, CREDIT AND BANKING, 37.6, Dec., 977-999 (2004) (see particularly p. 978 and Table 4) estimate even larger output losses. A study of 23 such crises found only four countries that attained their pre-crisis trend level of output within 17 years. Typically, there was a drop in output, followed by a period of stagnation, until a return to the trend growth rate. The same study measures the accumulated loss of output this entails in several ways, and depending on which they take, the authors calculate the average capitalized loss as equivalent to between 7 months and 3 years of real GDP. One example of a crisis of this order of magnitude is the Norwegian banking crisis and recession in the early $1990 \mathrm{~s}$.

32 Competitively neutral macroeconomic stimulus is necessary for Keynesian reasons. Subsidies for retraining, regions, environmental protection, and fundamental $R \& D$ may rightly be given to correct a specific externality or for distributional reasons. However, it is sometimes difficult to make the sharp distinction between these so-called "horizontal" state aids and the more discriminatory and so distortionary sectoral- or firm-specific aid.

33 See the EAGCP advice on Rescue and Restructuring Aid which was written shortly before the current crisis: available at http://ec.europa.eu/dgs/competition/economist/eagcp.html.

34 This can be thought of as an option value of being in the industry should demand pick up. Similarly entry is delayed by the option value of not having committed to the sunk costs of entry. See Avinash Dixit, Entry and exit decisions under uncertainty, J. PoLITICAL ECon.97.3, 620-38 (1989); also Robert S. Pindyck, Sunk Costs and Risk-Based Barriers to Entry, NBER Working Paper \#14755, (2009).

35 See Marvin B. Lieberman, Exit from Declining Industries: "Shakeout" or "Stakeout"?'21 RAND 4, 538-554 (Winter, 1990) for empirical evidence and references to the theoretical foundations and other empirical findings. See also: Andrew B. Bernard \& J. Bradford Jensen, Firm Structure, Multinationals, and Manufacturing Plant Deaths, LXXXIX.2 R. ECON. \& STATISTICS, 193-204 (May 2007); and Mary E. Deily, Exit Strategies and Plant-Closing Decisions: The Case of Steel, 22 RAND 2, 250-263, (Summer, 1991).

36 This is not a claim that all free market structures are ideal in the theoretically abstract sense of what might be designed by a perfect planner with all the available information.

37 Highly leveraged or indebted firms are more likely to exit before their less leveraged rivals, at least in concentrated markets. See Dan Kovenock \& Gordon M. Phillips, Capital Structure and Product Market Behaviour: An Examination of Plant Exit and Investment Decision, 10 R. FINANCIAL STUDIES 3, 767-803 (Autumn, 1997).

38 Lending should depend on ability to repay (outside the immediate crisis period), which does not mean a return to the precarious policies of the last decade. This form of state lending is accepted by the European Commission under what is known as the "market economy investor principle" and is relevant for both State aid and State owned firms.

39 Beyond political impact, it tends to be declining industries with concentrated market structures that have the greatest incentive to invest in lobbying activities because they face a smaller free-rider problem in reaping the rewards. See Frederick Robert-Nicoud and Richard Baldwin, Entry and asymmetric lobbying: why governments pick losers, 5.5 J. EuR. Econ. Assoc. (2007), 1064-93.

40 Arguments may also be made in relation to agglomeration economies by which a region develops a network of supply links and support services that benefit many independent firms. However, it is unlikely that even the current recession could overturn genuine long-term agglomeration economies. Detroit is sometimes used as an example from the car industry. However, it is notable that Japanese car manufacturers mostly chose to locate far from Detroit for their successful entry into the United States. 
41 Nevertheless, specific sectors clearly have an incentive to obscure this fact and firms may collude in search of State aid. For example, GM and Chrysler approached Washington together, and Renault and Peugeot-Citroen approached Paris together.

42 For a review, see Kyle Bagwell \& Robert W. Staiger, Protection and the Business Cycle, (January 2003), mimeo.

43 Daniel A. Crane, Antitrust enforcement during national crises: an unhappy history, GCP MAGAZINE, 9 (December 2008). Available online at www.globalcompetitionpolicy.org.

44 The examples and estimates in this paragraph are taken from Harold L. Cole \& Lee E. Ohanian, New Deal Policies and the Persistence of the Great Depression: A General Equilibrium Analysis, $112 \mathrm{~J}$. PoL. Econ. 4, (2004).These findings have been challenged by Gauti Eggertsson, Was the New Deal Contractionary?' Federal Reserve Bank of New York Staff Report no. 264 (2006), but Cole \& Ohanian are more persuasive. Note also the Robinson-Patman Act (1936) prohibiting price discrimination and various other "fair trade" laws that were arguably too interventionist, were also passed during the Great Depression, as was the Smoot-Hawley Tariff Act (1930).

45 There is also evidence that lack of competition unnecessarily prolonged the 1990s Japanese recession. See Michael E. Porter \& Mariko Sakakibara, Competition in Japan, 18 J. ECON. PersPeCtives 1, 27-50, (2004).

46 In the state of panic at the time, the Secretary of State was supported by a powerful triumvirate of the Bank of England, Financial Services Agency, and Treasury on grounds of short-term financial stability. John Vickers argues that this aim might have been achieved in a less anticompetitive way, see John Vickers, The financial crisis and competition policy: some economics, GCP MAGAZINE (December 2008). The merger creates a balanced duopoly in SME banking in Scotland, with the other duopolist being the crippled and near-nationalized RBS (see \#158-9 of the OFT's Anticipated acquisition by Lloyds TSB plc of HBOS plc: Report to the Secretary of State for Business Enterprise and Regulatory Reform, (24 October 2008), available at http://www.oft.gov.uk/shared_oft/press_release_attachments/ LLloydstsb.pdf). In the United States, emergency takeovers of Bear Stearns, Merrill Lynch, and Wachovia among others may have also been problematic.

47 The Act does allow for such a political decision on the grounds of public interest though this was intended to be interpreted narrowly, with national security as the only stated example plus a public interest provision to maintain media plurality (R. WHISH, COMPETITION LAW, 898 (2001)). A new public interest "to ensure the stability of the UK financial system" had to be created in a formal Order to be passed urgently by both Houses of Parliament. Note that national security and media plurality are appropriately long-term considerations for a merger, whereas this merger's contribution to financial stability could only have been short-term at best. In fact, subsequent events have shown that HBOS was sitting on a loss of $£ 10$ billion in bad debts that Lloyds TSB failed to notice in its highly compressed and partial "due diligence." Consequently, two banks have been crippled instead of just one.

48 Paul Krugman, Protectionism and stimulus, on his blog dated 1 February 2009: http://krugman.blogs.nytimes.com/2009/02/01/protectionism-and-stimulus-wonkish/.

49 The Market Economy Investor Principle ("MEIP") allows a State injection of funds as long as this is on "terms which a private investor would find acceptable in providing funds to a comparable private undertaking when the private investor is operating under normal market-economy conditions;" $0 \mathrm{~J}$ C307, 13.11.1993, \#11.

50 For a succinct explanation of EC state aid rules as applied to banking, see Christopher Vajda, The banking crisis and EC state aid rules, BUTTERWORTHS, 67-69, (2009).

51 Temporary framework for State aid measures to support access to finance in the current financial and economic crisis, Communication from the Commission, (26 November 2008). By the end of July 
2009, 24 countries had taken advantage of the new rules and 55 non-bank aid schemes had been approved by the Commission under the Temporary Framework. See EC MEMO/09/67 and MEMO/09/380. Specific allowable measures are: up to EURO 0.5m cash grant per firm, provided the aid does not favor exports or domestic over imported products (which will be very hard to police); reductions of 15 percent ( 25 percent for SMEs) on loan guarantee premia for loans up to the size of the annual wage bill; relaxed rules on interest rate subsidies; 25 percent subsidies ( 50 percent for SMEs) for investment in green production; and provision of risk capital for SMEs. It is interesting to compare the incidence of these general schemes for the real sector with the bank rescues over the same period, where 18 Member States had 66 bank rescue or more general bank guarantee-type schemes approved by the EC.

52 More precisely, the relaxation is limited to SMEs plus firms that were not in difficulty before July 1, 2008.

53 See Dewatripont \& Seabright, Wasteful public spending and state aid control, J. EuR. ECoN. Ass' N 4.2/3, 513-22 (2006), on the commitment value of EU State aid rules. The United States has no equivalent to the EC for reviewing rescue and restructuring aid. One commentator suggests the United States needs a DoJ Deputy Assistant Attorney General for emergency restructuring to represent the interests of competition. See Albert Foer, 'Too big to fail?' The role of antitrust law in governmentfunded consolidation in the banking industry, statement before the U.S. House of Representatives Judiciary Committee, sub-committee on courts and competition policy (March 17, 2009.

54 For example, the Doha round of trade liberalization was started in 2001 and is still struggling for agreement.

55 Other international institutions are also advocating an appropriate role for competition policy during the recession. For example, the Director-General of the OECD, Angel Gurría, has called for strong competition policy to speed recovery, OECD press release (February 19, 2009).

56 For further examples, see John Fingleton, Competition policy in troubled times, (speech dated January 20, 2009), available at http://www.oft.gov.uk/.

57 See, for example: Margaret Levenstein \& Valerie Suslow, What determines cartel success? $44 \mathrm{~J}$. EcoN. LIT. 1, 43-95 (2006), pp. 43-95; Simon Evenett, Margaret Levenstein \& Valerie Suslow, International cartel enforcement: lessons from the 1990s, WORLD ECON. 24.9, 1221-45 (2001).

58 See also Andre Fiebig, Crisis cartels and the triumph of industrial policy over competition policy in Europe, BRooklyn J. INT'L L., XXV.3, 607-38; and Richard Whish, Competition Law, ButTERWORTHS, 577-8 (2003).

59 See for example: Gary Becker, Crime and Punishment: An Economic Approach, J. Pol. Econ 76.2, 169217 (1968); Mitchell Polinsky \& Steven Shavell, The Economic Theory of Public Enforcement of the Law, J. Econ. Lit. 38, 45-76 (2000); and M. Motta, Competition Policy: Theory and Practice, (2004).

60 The Lloyds TSB HBOS merger was not allowed on a classic failing firm defense, which is that if a firm is going to exit the market anyway, there will be no additional loss of competition due to the merger. As already described, the ministerial intervention in that case was on public interest grounds supposedly "to ensure the stability of the UK financial system."

61 The OFT appreciates this in its Restatement of OFT's position regarding acquisitions of "failing firms" December 2008, OFT1047.

62 Behavioral remedies may be feasible for some mergers, particularly if there is a natural way of enforcing them and if the competition problem is expected to be short-lived.

63 For example, Olivier Besancenot has achieved instant popularity in France by setting up the Nouveau Parti Anti-Capitaliste ("NPA"). 